\title{
POSSIBILITIES OF WASTE REDUCTION IN GASTRONOMY AND FOOD INDUSTRY IN THE CONTEXT OF CIRCULAR ECONOMY
}

\author{
Petr STUDNIČKA
}

The Institute of Hospitality Management in Prague, Department of Hotel Management

\begin{abstract}
The aim of the article is to propose approaches to waste reduction in gastronomy and food industry in the context of the White Paper for Hospitality in Europe: 2019-2024 EU Mandate and the circular economy. White Paper presents the industry's top five priorities - Collaborative economy, Better regulation, Digital, Food Policy and Social Affairs. The priority Food Policy shows that voluntary measures, as the ones which took the European hospitality industry together with the European Food Banks Federation (FEBA) to reduce food waste and develop food donations, are proving their effectiveness and therefore favourably replace European-wide legislation in this case. Waste in gastronomy and food industry can be classified into two areas, organic and inorganic waste. Organic waste constitutes a percentage of purchased but unused food and directly translates into the finances of customers. Inorganic waste is more dangerous because it is associated mainly with the packaging necessary for packing food to go. The possibilities of reducing waste in gastronomy are summarized based on own primary and secondary research. Better knowledge of options of residual foodstuffs disposing/management could be achived not only by explaining legislation and real options of disposing waste but also by providing various recommendations and ideas to restrict residual foodstuffs and food waste.
\end{abstract}

Key words: circular economy, food industry, gastronomy, residual materials, waste management

\section{Introduction}

Food service industry waste is a growing problem worldwide. Yet, according to Condamine (2020) of Zero Waste Europe, almost $50 \%$ of food waste does not occur in our refrigerators, but rather in the steps before consumption, from production to food service. For example, around $30 \%$ of food waste in Europe is generated in the production and processing steps (Nestle, 2013).

The HORECA segment is a significant waste producer. Very few catering companies sort all types of waste and implement waste reduction principles. This is why this segment is important in the search for a more responsible and sustainable way with the application of circular economy principles. An important document is the White Paper for Hospitality in Europe: 2019-2024 EU Mandate (HOTREC, 2019) and the 3 Rs (reuse, reduce, recycle) principles mentioned therein.

The aim of the thesis is to propose approaches leading to waste reduction in the food service industry in the context of the White Paper and the circular economy. The research questions and hypotheses are defined as follows:

1. What are the opportunities for reducing waste in the food service industry in the world and in our country?

https://doi.org/10.11118/978-80-7509-820-7-0136

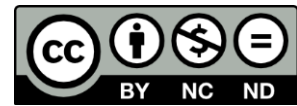


2. What can motivate food service industry operations and what are the potential barriers?

$\mathrm{H} 1$ - We believe that there is more practice in reducing waste in the food service industry abroad than in the Czech Republic.

$\mathrm{H} 2$ - We assume that food service industry operations in the Czech Republic are not motivated to reduce waste.

In recent decades, sustainable development has penetrated the food service industry as well - food waste is a global problem right now. According to a 2013 UN report, 1.3 billion tonnes of food are thrown away or spoiled worldwide annually, a third of total food production, and worth nearly $£ 20$ trillion. Of this, around 300 million tonnes of food is still fit for consumption. In Europe, $95-115 \mathrm{~kg}$ of food per capita is wasted each year.

In the Czech Republic, this trend in gastronomy has only emerged in recent years. Food waste is particularly serious at the agricultural and household level, but food service establishments also contribute to it to some extent. Waste in restaurants is not the most voluminous, but they could still reduce its volume and prevent unnecessary waste. Closely related to the further use of residual raw materials is the principle of Zero Waste, i.e., processing raw materials so that no or minimal residues are generated.

\section{Literature review / Research Background}

The term "food service industry" includes any company that manufactures, processes, sells and serves food, beverages and nutritional supplements. It refers to all stages of the process, including design, construction, maintenance and delivery of solutions to customers in the animal nutrition and food industry (food and beverage) (Hlavatá, 2018, Vezérová, 2021). The food industry has different characteristics compared to other manufacturing industries. According to McIntosh et al. (2010), there are several factors to distinguish between the food industry and other manufacturing industries. These include chemical change, ripening cycles, delay and decomposition of the food product. Gastronomy is concerned with the influences (mainly culture and environment) that affect people's diets from the selection of ingredients to the way they are finally consumed.

As the EU's largest manufacturing sector, the food and drink sector represents an important pillar of the EU economy with a turnover of $€ 965$ billion and contributes $2 \%$ of GDP. Half of the sector's turnover is produced by small and medium-sized enterprises, which form a crucial part of the business base and process the bulk of agricultural production. The sector has a positive trade balance in the EU and employs 4.4 million people. In the Czech Republic, food and beverage production contributes $2.7 \%$ of GDP. Similarly to the EU, the sector is a mainstay of the manufacturing industry in the Czech Republic, with a diversified size structure of enterprises. The importance of the food industry is primarily due to the fact that it ensures the nutrition of the population by producing products that are safe for health, of high quality and widely available, including regional specialities and organic food. On the other hand, this sector, together with the gastronomy, is characterised by a 
high proportion of waste produced, which consists mainly of organic residues from processed raw materials and also packaging that has been used to protect against potential pathogenic influences (EU-MERCI, 2020).

For the past 150 years our industrial economy has been dominated by a one-way production and consumption model in which goods are produced from raw materials, sold, used and then burned or thrown away as waste. With a growing global population and the associated increasing consumption of resources and negative environmental impacts, it is becoming increasingly apparent that the current way of doing business is no longer suitable for a sustainable future. While the concept of a circular economy has been discussed since the 1970s, the transition from the current linear economic model to a circular model has recently attracted increased attention from major global corporations and policy makers. The circular economy emphasizes process redesigning and materials recycling that can contribute to more sustainable business models and maximize ecosystem functioning and human wellbeing (Korhonen et al. 2018). The identification of the environment for evaluation and development of culinary tourism is an important step in thrise strategic decisionmaking process from which they are derived development of products, choice of price tools and other tasks of the destination management focused on health and human well-being (Plzáková, Stupková, 2019). New trends in tourism involve tourism demand individualization, the need for greater flexibility in decisionmaking, accelerated selection, booking and payment for services, and last but not least, immediate feedback from customers (Plzáková, Studnička, 2021).

According to Fiedor (2012), most human activities generate waste and its amount has recently been increasing in a still more rapid way. With the volume, the diversity increases as well. The concept of Zero Waste comes from the highly successful Japanese industrial concept of total quality management. Transferred to the municipal waste sector, Zero Waste draws attention to the entire product life cycle (Murray 2002).

Gastro waste is an inherently large part of the waste stream and has been the focus of many studies in recent years. According to the European Parliament (2017), onefifth of all food produced in Europe becomes waste, equivalent to 88 million tonnes of food per year. This means that 92 kilograms of food per capita are thrown away each year. The European Commission (2020) reports that the EU Circular Economy Action Plan aims to help achieve the Global Sustainable Development Goal target of halving per capita food waste at retail and consumer level by 2030 and reducing food loss in production and supply chains.

In gastronomy, we think of packaging waste from raw materials and waste from disposable takeaway packaging. The use of single-use plastic packaging increases convenience, promotes on-the-go culture and in some cases extends shelf life. Packaging waste has grown along with food waste, which poses a huge challenge. Since the use of plastic food packaging became commonplace in Europe in the 1950s, levels of plastic packaging and food waste per capita have risen simultaneously, with annual levels exceeding 15 million tonnes or $30 \mathrm{~kg}$ of plastic packaging waste per capita. While both food and packaging waste have started to 
decline in recent years, the amount per capita remains at its highest level on record (IEEP 2018).

\section{Methodology}

In-house research was used to test the above stated hypotheses. As the own research is not sufficient to fulfil the objectives, it was necessary to conduct a structured interview with the project manager Barbora Kebova (2020), who is in charge of gastronomy at the Institute of Circular Economy and is an expert in this field. The interview was based on pre-prepared questions:

1. Do you think that companies operating in the catering and food industry in the

Czech Republic are sufficiently involved in waste reduction?

2. What do you think are the most effective solutions to reduce waste?

3 . Which part of the process generates the most waste? Why?

4. Do you know of any technologies and innovations that help in waste prevention?

The research methods used in this thesis were a comparison of individual examples of good practice, analysis of professional documents, structured interview, evaluation of the interview with a comparison of the actual research.

\section{Results}

In 2018, the non-profit organisation Zachran jídlo participated in the research project Reducing Food Waste in Public Catering (RedPot), which was co-operated by the Technology Centre of the CAS, Median and the Institute of Agricultural Economics and Information. The resulting materials are intended to help catering businesses, government and non-profit and other organisations that want to reduce their food loss and waste for environmental or economic reasons. Canteens could save money by using an ordering system and adjusting portion sizes. Fast food businesses should review their strict corporate standards for food quality.

How canteens and fast food outlets can reduce the amount of food they throw away: (1) stock control - overview of food stocks, longer shelf life, (2) enable norms - if possible, extend the time of serving food, (3) involve staff - regular training and supervision of more experienced newcomers, (4) inform customers - avoid wastage, regular satisfaction survey, (5) entice with a discount - using e.g. Nesnězeno or Jídlo apps, (6) utilize technology - vacuum packaging and portion cooling, (7) donate raw materials and portions - subject to meeting hygiene standards, (8) sort - separate bio-waste, sorted waste is cheaper to take away, (9) plan - use ordering systems and (10) adjust portions - offer smaller portions; show pictures rather than exposed sample portions.

Zachraň jídlo released its first cookbook in 2019, listing recipes with the goal of not wasting and using every part of the food. The organization also offers corporate packages for businesses where employees gain knowledge on how to prevent and utilize food waste (Table 1). 
Table 1. SWOT analysis of the current state of involment in waste reduction in the food service industry

\begin{tabular}{|l|l|}
\hline Threats & Opportunities \\
\hline & Customer education \\
Insufficient package free assortment of & Waste monitoring \\
larger suppliers & Smaller package free suppliers, farmers \\
Rising waste disposal charges & $\begin{array}{l}\text { Savings of waste collection } \\
\text { Consultancy }\end{array}$ \\
\hline Weaknesses & Strenghts \\
\hline Time options & Motivation of employees \\
Internal measures & Motivation of owners \\
Lack of innovation, technology & Better reputation \\
\hline
\end{tabular}

Source: own processing

The food service industry produces a large amount of diverse waste on a daily basis. In our experience, the largest part is made up of packaging materials - be it plastics, paper, glass, beverage cartons or metals. And there is no shortage of organic waste either. Reduction of food waste depends mainly on its monitoring, effective menu planning and composition, and the skills of the staff. It can therefore be substantially reduced by internal measures within the operation.

For packaging waste, of course, it helps to buy in larger packages (but so that food doesn't go bad before the kitchen can use it) or in more concentrated forms for example, for cleaning products. When it comes to mixed waste, it is important to sort it consistently and motivate your own staff to do so. An effective on-site bin system may be helpful for staff in making sorting as easy as possible. In most food service establishments, most waste is generated in the preparation area - in the kitchen and behind the bar. This is where most of the packaging materials come from as well as most of the organic waste in the form of food scraps and leftovers.

Systems such as Winnow or LeanPath help to monitor and reduce food waste in food service operations. There are also systems for single-use, returnable and reusable dish ware systems such as ReKrabička. Prepared meals are being saved from waste by "rescue" apps such as TooGoodToGo or the Czech Nesnězeno. Packaging doesn't always have to be bad if it helps to extend the shelf life of food or save food from being thrown away by someone taking it home. There are a number of innovations in packaging technology in general today, whether targeting the durability of food or the recyclability of the materials used.

\section{Discussion}

According to Act No. 185/2001 Coll., on Waste, waste is "any movable thing that a person gets rid of or intends to get rid of". Waste itself can be divided into different aspects. The division can be aided by Decree No. 93/2016 Coll., on the Waste Catalogue, which distinguishes waste as hazardous and other waste, and further divides it into a total of twenty waste groups, which contain almost a thousand types of waste. For biodegradable waste from kitchens and food service establishments, 
the term gastrowaste is currently used. In the waste catalogue, it is in the municipal waste section under the number 200128 . Such waste can be, for example, leftovers from production and consumption, products that are not of the required quality, expired products or contaminated materials.

Waste management supports the operators in prevention of the very generation of excessive waste, which is not only the statutory obligation, but also the basic pillar of sustainable development. Act No 185/2001 Coll., on waste, lays down the obligation to follow a sequence of waste management methods: (1) waste prevention (economical behaviour in waste production), (2) preparing for re-use (finding alternative uses), (3) recycling (using waste to create new products), (4) other uses of waste (e.g. energy production), (5) waste disposal (only otherwise unusable waste).

Due to legislative restrictions, it is almost impossible to use unused raw materials in a food service industry. For example, the regulation lays down the conditions for using kitchen waste for feeding.

Most of the international research on food waste started after 2000. Selected studies show that reducing residual raw materials is quite difficult for food service establishments (especially in institutional catering). Solutions may include menu adjustments, smaller portions or more effective marketing to encourage non-waste. The authors of the study Biting Off More Than They Can Chew - Food Waste at Hotel Breakfast Buffets (Juvan, Grün, Dolnicar, 2018) focus on the food waste generated by breakfast buffets in hotels. Another interesting foreign study on this topic is Can Marketing Help in Tackling Food Waste?: Proposals in Developed Countries (Calvo-Porral, Faina, Losada-Lopez, 2017). This study explores how appropriate marketing could lead to a reduction in food waste. It starts from the fact that waste occurs at all stages of the supply chain and that purchasing behaviour in developed countries has reached a stage where a culture of not producing leftovers has turned into a society where waste is now accepted as a part of life. The Danish study Reducing Food Waste in Large-Scale Institutions and Hospitals: Insights From Interviews With Danish Foodservice Professionals (Ofei et al., 2015) explores the experiences of food service professionals and their strategies for reducing food waste in large institutional kitchens

Food waste is particularly serious in developed countries, where it occurs at the level of sale and consumption (as opposed to developing countries, where almost half of the losses occur at the processing stage). In developed countries, wastage is most significant at the consumption level (most food waste is from households) and is mainly due to consumer purchasing behaviour and habits, together with cultural and social factors. The consumer society, combined with efficient production and mass marketing, leads to serious food waste and it is for these reasons that appropriate marketing could help to address this problem. In the context of catering, the study draws particular attention to the production of more food than is ultimately necessary in buffet establishments. It also identifies the three most common causes of food waste in restaurants: poor storage and subsequent spoilage, poor planning of meal numbers leading to more food being prepared than is consumed, and failure to process food already prepared, but not served. 


\section{Conclusion}

The issue of waste in the food service industry is a global problem with a large enough contribution to climate change. Yet the number of people who do not have access to food is staggering. Many businesses do not yet know how to approach and prevent waste. The time and money invested ends up in landfill sites and never fulfils its potential.

Food waste is a global problem and in the Czech Republic it is only in recent years that it has become more prominent. In the gastronomy sector, international trends such as taste waste or zero waste have only recently emerged and have been slow to come to public attention. However, the survey shows that restaurant operators have always applied zero waste principles to varying degrees in their businesses. Operators do not try to reduce residual raw materials so much for environmental reasons as for economic and cost-saving reasons. Thus, on the part of operators, saving raw materials is natural and essentially unconscious. However, society should, above all, talk and inform more about this issue so that people start thinking more about waste and try to reduce it. Restaurant and canteen operators should also be made more aware of zero-waste practices and the possibilities for managing residual raw materials, as they may not be aware of them or have nowhere to learn about them.

In many cases, it is also the guests themselves who are behind the waste in restaurants. Waste at the production level can be kept to a minimum by the restaurant, but reducing waste at the sales level is more difficult. Implementing measures to reduce waste by guests can also be problematic, as it could discourage guests from visiting again or worsen the restaurant's reputation and discourage new guests from visiting. Operators may also be discouraged by the time and security involved in some measures.

Waste in food services has not been significantly addressed in the Czech Republic and is a relatively new topic. Gradually, projects and trends concerning waste in restaurants are beginning to emerge, but there is also a tendency towards a deeper investigation of the current situation. Restaurant operators themselves should focus more on waste and start reducing residual raw materials, but also informing guests about the issue. The main point now is that even if individual operators contribute minimally to the overall reduction of leftovers, they can inspire other businesses and consumers to think about the issue of waste.

\section{References}

1. Calvo-Porral C., Faina M., Losada-Lopez, C. (2017), Can Marketing Help in Tackling Food Waste?: Proposals in Developed Countries, "Journal of Food Products Marketing", 23, 1, pp. 42-60, DOI: $10.1080 / 10454446.2017 .1244792$.

2. Condamine P. (2020), Zero Waste Europe, https://zerowasteeurope.eu/about/principleszW-europe/ (access: 18-04-2021). 
3. EU-MERCI (2020), Analysis of Food and Beverage Sector in Different Countries, http://www.eumerci-portal.eu/documents/20182/38527/10+-+Other+countries.pdf (access: 15-04-2021).

4. European Commission (2020), A Farm to Fork Strategy, http://www.fao.org/agroecology/database/detail/en/c/1277002/ (access: 05-05-2021).

5. European Parliament (2017), Food waste: the problem in the EU in numbers. https://www.europarl.europa.eu/news/en/headlines/society/20170505STO73528/foodwaste-the-problem-in-the-eu-in-numbers-infographic (access: 23-04-2021).

6. Fiedor J. (2012), Odpadové hospodářství - učební text, Vysoká škola báňská, Ostrava.

7. Hlavatá B. (2018), Možnosti zpracováni a omezování zbytkových surovin z restaurací, Vysoká škola hotelová (Master's Dissertation), Praha.

8. HOTREC (2019), White Paper for Hospitality in Europe: 2019-2024 EU Mandate, HOTREC, Brussels.

9. IEEP (2018), Unwrapped: how throwaway plastic is failing to solve Europe's food waste problem (and what we need to do instead), IEEP, Brussels.

10. Juvan E., Grün B., Dolnicar S. (2018), Biting Off More Than They Can Chew: Food Waste at Hotel Breakfast Buffets, "Journal of Travel Research", 57, 2, pp. 232-242, DOI: $10.1177 / 0047287516688321$.

11. Kebová B. (2020), Cirkulární ekonomika v gastronomii, https://hub.cirkularnicesko.cz/wp-content/uploads/2020/06/Webinář_CE-vgastronomii_ppt.pdf (access: 22-04-2021).

12. Korhonen N. et al. (2018), Circular Economy: The Concept and Its Limitations. Ecological

Economist, https://www.researchgate.net/profile/Jouni_Korhonen2/publication/318385030_Circul ar_Economy_The_Concept_and_its_Limitations/links/5a53e343a6fdccf3e2e28b99/Cir cular-Economy-The-Concept-and-its-Limitations.pdf (access: 07-04-2021).

13. McIntosh R.I. et al. (2010). Late customisation: issues of mass customisation in the food industry, "International Journal of Production Research", 48, 6, pp. 1557-1574. DOI: $10.1080 / 00207540802577938$.

14. Murray R. (2002), Zero Waste, Greenpeace Publications, London.

15. Nestle M. (2013), Food Politics: How the Food Industry Influences Nutrition and Health, University California Press, Berkeley.

16. Ofei K.T. et al. (2015), Reducing Food Waste in Large - Scale Institutions and Hospitals: Insights From Interviews With Danish Foodservice Professionals, "Journal of Foodservice Business Research", 18, 5, pp. 502-519. DOI: 10.1080/153780020.2015.1093457.

17. Plzáková L., Studnička P. (2021), Local Taxation of Tourism in the Context of the Collaborative Economy - Case Study from the Czech Republic, "Lex Localis - Journal of Local-Self Government”, 19, 1, pp. 65-89. DOI: 10.4335/19.1.65-89(2021).

18. Plzáková L., Stupková L. (2019), Determination of Key Factors of Health and WellBeing Tourism Destinations, IBIMA, Granada.

19. The Act of 14 June 2001 Waste Law (Collection of Laws 2001 no 185 item 71).

20. The Decree of 31 March 2016 Catalogue of Waste (Collection of Laws 2016 no 93 item 38).

21. Vezérová K. (2021), Možnosti snižování odpadu v gastronomii a potravinářství v kontextu cirkulárni ekonomiky, Vysoká škola hotelová (Master's Dissertation), Praha. 